年庭は， R. rattus は $58 \% ， R$. norvegicus は $42 \%$ と R. norvegicus が多くなつてきた傾向が見られる。この

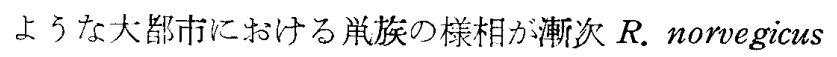
の復位を星示しつつある傾问は注目に值する。性比につ いては市街地区，㦈謟地区とも市の方が優梦である。外 部寄生虫について情地区ともネズミトゲダニ, ネズミ ジラミ，ヤマトネズミノミ，ヨーロッパネズミノミ等が 少しずつ見られるだけであり，年年少なくなつているよ らである。

(阪市大・医動物)

\section{L, 三の環境における住家性ネスミの捿息状況及び駆除} 法の検討：長田泰博 Osada, Y.： Studies on the behavior and control of the commensal rats under several different environments

畜舎やデパート其他のビルに怙けるネズミの集团に詨

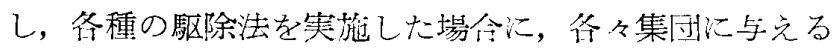
影䪪, 效果の比較を行つた。また，無青㖉の提取状況々 共にこれら建物内に和ける樵息数や集団の実態を推祭す る為の実験を行つた。

冬環境における枚息状況は，畜含の場公，ドブネズミ Rattus norvegicus が比較的狭い範罒で多数婪息した. また，その他のビルの場合，地階から屋上に至るまでの

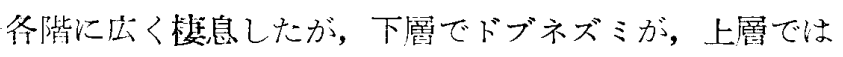
クマネズミ Rattus rattus が優勢を示し, 丽種の混在も みられた。駆除法と集団の影響については，畜含では最 初に一定の方法で捕殺を行つた場合にはかなりの捕獲が むつた。集団の回復後, 記号放逐を実施しさらに前回同 様の捕殺を行つた效果以著るしく低く, 集団には大した 変化はみられない、これは記号放逐された多数の個体が ワナを忌避したことが大きな原因と考えられ，記号放 逐の結果から推察される梅息数よりかなり少い推定值が 得られた。次にこの集団に対して薬剤を碑い, 異る駆除 法を実施した場合には反応も以前と暴り效果が著るしい が，薬剂配置を行わなかつた同含半棟の集団には大した 影響がなかつた。これは集団内の活動範用が或る期間ご く限られていることに依ると考える.デパートなどのビ ルの場合喖息範国も広く, 位品関係では管理の不徽底か ら特に婑息数が多く，毒䬦の遙択 も畜含より著るしい

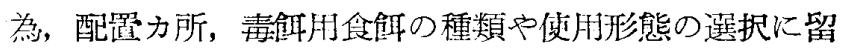
意を要した。これらの場所ではクマリン剂の固形, 粉末 用よりも同剤 $0.5 \%$ 濃厚未を油分を舍む食品に混じて全 館に広く配することによりほ添梅息を抑えることを得 tr.

（伝研・寄生虫）

\section{狺号放逐法によるネスミ毒殺率算定実例の再分析と批}

制: 由中亮 Tanaka, R.：A criticism on some examples offering a kill-efficiency by the markand-release census of pre- and post-poisoning vole populations

㲹号放逐法を用いて，毒殺前後のセンサスをして毒殺 率を算定する方法は先に筆者が提出した。この場合, 七 ンサスと毒殺が引続いてなされて毒殺後も清殺前の捕磼

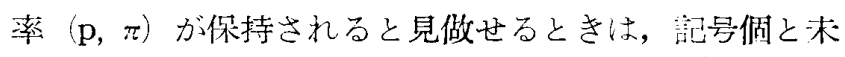
記号個の残存率 $\left(r ， r^{\prime}\right)$ が簡単に算出されるが，もし毒 殺後 $\mathrm{p}, \pi$ を新たに推定しなければならない事情の下で

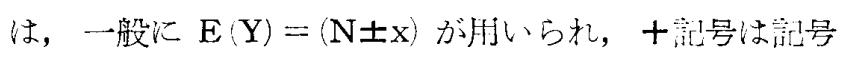
個に邀封されなければならない。

宇出川ら (1958 林試研究報告 No. 105) はハタネズミ のトタンがこい 1 ha plot 個体群に対して, 毒殺前は 号放逐，後は除去法によつてセンサスをなし，数種の毒: 剤の効率を比較した。この資数分析に方法論的に不遁切 な点があるので，筆者は彼等の plot 1 と plot 4 の捕獲 資料を再分析してみると興味ある結果が究られた。筆者 が計算した毒殺前のNの最大推定值に比べると, 彼等が 园解法でえたN值は明かな過小詊洒でありここような 誤りは，この場合のように p が葚だ小さい時に起り易 く, p 小さいのはN比して罠率度が小さすぎるから である。これはわれわれが実施している研究から推測で きる. 毒殺後の除去法資料から最大推定值を算出してみ ると, 捕確率は毒殺前のむのよりはるかに大きい。これ はハジキ罠を归いたことと罠数が3售になつたことによ る. 毒殺前後の推定值から毒殺率を算出すると, 们号 個と末䛅号個では $10 \%$ 差子現われた。残存者の多い plot 4 で, もし毒殺後它記号放逐したと仮定して, 毒殺前 の捕確率を遁团すれば期待捕獲数が算出できる。このさ い前の既記号個を記号個とみなすか，末記号個と又るか の 2 方法があるが，何れの方法でも同一な毒殺率がえら れたが，前者の方が簡単にできる。なお Jameson (1958) はすべて記号放逐で同様な研究をしたが，Nの推定は Lincoln 示数法でなした。この結果は $\mathrm{p}=\pi$ が保証され ない戉り信頼性が少くこのことは上の分析資料でも実 証される.

(高知女大・動物) 